\title{
Criação e recriação: um olhar para a obra do poeta e tradutor Paulo Henriques Britto
}

Writing and rewriting literature: A Brief Analysis of the Work of Poet and Translator Paulo Henriques Britto

\author{
Leila Cristina de Melo Darin
}

Pontífica Universidade Católica - PUCSP - São Paulo - Brasil

\author{
Vivian Chazan Bartolomeu \\ Pontífica Universidade Católica - PUCSP - São Paulo - Brasil
}

\begin{abstract}
Resumo: Partindo do pressuposto de que escrever um texto literário e reescrevê-lo em outro idioma são práticas intertextuais que nutrem uma à outra, o presente artigo se propõe a analisar a relação entre produção literária e tradução literária na obra do poetatradutor brasileiro Paulo Henriques Britto, especificamente em sua mais recente publicação, Nenhum mistério (2018). O título do livro remete à tradução do poema de Elizabeth Bishop intitulado "One Art", cujo primeiro verso Britto assim traduz: "A arte de perder não é nenhum mistério" (2001). Com base na leitura e discussão de textos sobre tradução literária (CAMPOS, 1981, 2013; ARROJO, 1993, 2007; BORGES, 1986; PAZ, 2009; CARVALHAL, 1993; BRITTO, 1999, 2012), são examinados três poemas de autoria de Britto - "Nenhuma arte", "Nenhum mistério" e "Ao sair da sala" - que sugerem um diálogo com dois poemas traduzidos pelo poeta brasileiro, a saber, "One Art" de Elizabeth Bishop (2001) e "As you leave the room", de Wallace Stevens (2017). A análise possibilita a reflexão sobre as relações entre a prática tradutória de Britto e sua produção poética.
\end{abstract}

Palavras-chave: Tradução literária. Paulo Henriques Britto. Nenhum mistério. Uma arte. Nenhuma arte. Ao sair da sala.

\begin{abstract}
Based on the assumption that writing a literary text and rewriting it in another language are intertextual practices that nourish each other, this article aims to analyze the relationship between literary creation and literary translation in the work of Brazilian poet-translator Paulo Henriques Britto, specifically in his most recent publication, Nenhum mistério (2018). The title of the book refers to the translation of a poem by Elizabeth Bishop entitled "One Art", whose first verse "The art of losing isn't hard to master", Britto translated as: "A arte de perder não é nenhum mistério" (2001). To ground the analysis, we resorted to texts on the poetics of literary translation (CAMPOS, 1981, 2013; ARROJO, 1993, 2007; BORGES, 1986; PAZ, 2009; CARVALHAL, 1993; BRITTO, 1999, 2012), and three poems by Britto - "Nenhuma arte", "Nenhum mistério" and "Ao sair da sala" (2018). Analysis has shown that Britto's poems suggest a dialogue with two poems he translated into Portuguese, namely, "One Art" by Elizabeth Bishop (2001) and "As you leave the room" by Wallace Stevens (2017). The analysis allows for a reflection on the relationship between Britto's poetic writing and his translation practice.
\end{abstract}

Keywords: Literary translation. Paulo Henriques Britto. Nenhum mistério. One art. Nenhuma arte. As you leave the room. 


\section{LITERATURA: CRIAÇÃO E RECRIAÇÃO}

A tradução de textos literários é um tema controverso, sobre o qual se debruçam tradutores, teóricos, filósofos da linguagem, linguistas, antropólogos, escritores, poetas, críticos, intelectuais e leitores de diversas formações. Ao analisar o que se escreve sobre esse tipo de tradução, pode-se constatar a presença de dois argumentos "opostos": de um lado, os que acreditam na impossibilidade da tradução literária, pois, para eles, traduzir corresponde a destruir e violar a sagrada literariedade de uma obra; de outro, aqueles que defendem a viabilidade da tradução e pregam a dessacralização do original, pois entendem que o original não possui um sentido único e definitivo, mas está sujeito, como todo texto, a múltiplas leituras e releituras.

A natureza instável do sentido é discutida por Rosemary Arrojo (2007), que considera que todo texto é uma máquina de significados em potencial, sempre aberto a novas interpretações. Segundo Arrojo, o fato de o texto não ter um sentido estável, permanente, não significa que leitores e críticos sejam livres para interpretá-lo da forma como quiserem: para que uma interpretação seja aceita como legítima, é preciso que ela siga convenções textuais e critérios regulados por uma determinada comunidade.

Arrojo apresenta - e rejeita - a visão de certos autores, muitos deles escritores e poetas, que entendem a tradução como "destruição" do original. Dentre eles, Vladimir Nabokov se destaca pelas imagens depreciativas que apresenta sobre a tradução de poesia no texto "On translating 'Eugene Onegin"” (“Sobre a Tradução de 'Eugene Onegin'”), no qual equipara a tradução à "profanação dos mortos" (NABOKOV apud ARROJO, 2007, p. 26-7).

Para refutar essa concepção de tradução e defender sua posição, Arrojo pondera que não há consenso em relação ao que se considera "literariedade", já que a literatura, ao longo de séculos e civilizações, abarca as mais variadas formas de escrita. Com base no conceito de "comunidade interpretativa" de Stanley Fish (1980), segundo o qual o que se considera literatura é determinado por uma decisão, consciente ou não, da comunidade responsável por criar e regular sentidos, Arrojo argumenta que "Há textos que [...] nossa tradição cultural decide ler de forma literária ou poética" (ARROJO, 2007, p. 31). Em outras palavras, o "literário" é resultado do consenso de um grupo especializado, em um dado período e sistema cultural.

Quanto à "originalidade" do texto de partida, Arrojo mantém que, dada a interminável rede de intertextos que constituem uma cultura, o original não pode ser nem o lugar de origem de um ato de escrita, nem tampouco a fonte de algo absolutamente original, inédito. A posição da teórica assemelha-se à do poeta mexicano Octavio Paz, que igualmente questiona a singularidade do "texto original" como característica a distingui-lo dos demais textos. Para Paz, "todo texto é uma tradução porque a própria linguagem em sua essência já é uma tradução: primeiro, do mundo não verbal e, depois, porque cada signo e cada frase é a tradução de outro signo e de outra frase" (PAZ, 2009, p. 13). Assim, tanto o texto de partida como a tradução são formas de reescrita.

Por outra via de argumentação, a suposta "intraduzibilidade" poética é também rebatida por Haroldo de Campos. No ensaio "Da tradução como criação e como crítica" (2013), Campos afirma que a tradução da linguagem literária é possível por meio da "recriação", que se liga ao texto de partida por relação de isomorfia: "serão diferentes enquanto linguagens, mas, como corpos isomorfos, cristalizar-se-ão dentro de um mesmo sistema" (CAMPOS, 2013, p. 04). Para o poeta, criação e recriação não se encontram em relação hierárquica, pois ambas integram o sistema literáriocultural. Em seu ensaio "Transluciferação mefistofáustica" (1981), o autor declara que o objetivo da recriação, ou transcriação, é o de "obliterar" o original e desestabilizar sua suposta "superioridade". Por meio de um questionamento incisivo, o poetatradutor propõe inverter a ordem do raciocínio convencional: "converter, por um átimo que seja, o original na tradução de sua tradução" (CAMPOS, 1981, p. 180).

Poeta e tradutor, o argentino Jorge Luis Borges também desafia a "superioridade" do texto original. Em seu ensaio "As Versões Homéricas" (1986), Borges 
equipara tradução e escrita autoral, afirmando que nenhuma delas é superior, uma vez que ambas estão sujeitas às leis da recepção, da interpretação e da história. O autor utiliza a Odisseia como exemplo para argumentar que as inúmeras traduções da obra são todas elas genuínas e válidas, pois dialogam com o original a partir de variadas perspectivas culturais, temporais e linguísticas.

Observa-se que os autores citados partilham concepções similares a respeito da tradução literária, apesar de algumas divergências. Todos eles acreditam que: (a) a tradução literária implica na recriação ou transcriação do texto original, tendo, portanto, valor literário; e (b) a fidelidade na tradução é um critério ancorado em sentidos construídos socialmente: tradutores literários se pautam em suas visões de língua, literatura e tradução e em convenções de escrita literária. Vejamos, a seguir, como a concepção de Paulo Henriques Britto se situa em relação a esses pressupostos.

\section{A TRADUÇÃO SEGUNDO PAULO} HENRIQUES BRITTO

O escritor, tradutor e professor Paulo Henriques Britto é responsável por mais de uma centena de traduções literárias, além de nove obras de autoria própria, nos gêneros poesia, ficção e ensaio, dentre as quais encontra-se A tradução literária (2012). Nela, Britto discute sua visão de tradução literária e discorre sobre a tradução de prosa e poesia. Para o autor, a relação de oposição entre a traduzibilidade de obras literárias e a impossibilidade de tradução dessas obras é uma "espécie de extremismo teórico" (2012, p. 27). Como poeta e tradutor, acredita que é equivocado afirmar que a tradução literária é impossível; no entanto, a subversão da "originalidade", proposta por Arrojo e outros teóricos, não agrada a Britto, que entende o texto de partida e a tradução como textos que ocupam posições diferentes - o que, segundo ele, não quer dizer que mantenham entre si uma relação hierárquica. O poeta parece procurar um meio-termo ou uma aproximação entre os dois pontos de vista: concorda com a traduzibilidade da obra literária, mas defende que a tradução não deve tentar usurpar o lugar do texto de partida devendo o tradutor buscar ser o mais fiel possível ao texto que traduz. E o que é, para ele, fidelidade?

Britto discorda da afirmação que faz Arrojo (1993) no ensaio "A que são fiéis tradutores e críticos de tradução?" de que tradutores e críticos de tradução seriam fiéis às suas próprias concepções sobre tradução e literatura; para ele, isso tornaria praticamente impossível a tarefa de julgar a qualidade de uma tradução. O poeta-tradutor pondera que, apesar da subjetividade, deve-se buscar a objetividade, pois é possível determinar os aspectos mais importantes do poema, os quais o tradutor deve priorizar. $\mathrm{O}$ fato de 0 texto não possuir sentido estável não significa que o tradutor está livre para fazer o que quiser, pois há critérios a seguir: "Se a fidelidade absoluta, integral, perfeita é uma meta inatingível, nem por isso vamos abrir mão dela como orientação. O que o tradutor literário precisa fazer é relativizar essa meta" (BRITTO, 2012, p. 50, grifos do autor).

Chama a atenção que Britto desconsidere o fato de Arrojo incluir em sua discussão o papel da comunidade interpretativa como instância de controle dos sentidos, o que implica que o tradutor, em qualquer área em que atue, não é livre para traduzir como quiser.

Segundo Britto, o tradutor deve priorizar os aspectos mais relevantes do texto de partida para tentar recriá-los no idioma de chegada, mas sua visão não se afasta tanto da de Arrojo e de outros teóricos como alega o poeta. Afinal, ao selecionar o que deve e pode ser recriado, o tradutor inevitavelmente recorrerá não só às normas e valores cultivados pela comunidade de críticos, teóricos e estudiosos de literatura, mas escolherá, dentre eles, aqueles com os quais mais se identifica, revelando assim, o alto grau de subjetividade que rege 0 ato tradutório. Todas as decisões tradutórias são pautadas em valores e preferências pessoais, que variam conforme o conhecimento e a sensibilidade poética do tradutor. Coerente com a visão que condena os extremos, Britto prefere o termo "correspondência" a "equivalência", referindo-se ao estudioso estadunidense James Holmes, que "propôs que se parasse de falar em equivalência entre original e tradução, e em vez disso se utilizasse correspondência, 
um termo bem mais modesto e realista" (BRITTO, 2012, p. 19).

O que parece incomodar o poeta é a postura "extrema" dos que se propõem a desafiar a relação original-tradução. Embora considere a tradução de literatura como "recriação", para Britto há uma clara demarcação entre original e tradução. Ele é veemente ao criticar a ideia de Haroldo de Campos de que o objetivo da "transcriação" é "obliterar" o original, asserção com a qual não compactua. Para Britto, designar as traduções de Campos de 'transcriações' ou 'transluciferações', significa "cunhar neologismos de gosto discutível. As traduções de poemas feitas por ele e por Augusto são de excepcional qualidade, mas não deixam de ser traduções" (BRITTO, 2012, p. 131).

O foco do poeta carioca é o reconhecimento do texto original como fonte à qual a tradução para outro idioma deve procurar ser fiel, não em todos os seus aspectos, mas naqueles considerados mais relevantes: "na impossibilidade de recriar na sua tradução todos os elementos do original, cabe ao tradutor hierarquizá-los e escolher quais deles deverão ser privilegiados" (BRITTO, 2012, p. 37). Sua atuação como poeta certamente lhe permite uma maior compreensão e apreciação do material literário que traduz, norteando-o na seleção dos aspectos "mais vitais" aos quais a tradução deve ser fiel - fato que pode explicar o porquê da seleção lhe parecer quase "evidente". O critério de fidelidade vincula-se à reprodução do que ele chama de "efeito de literariedade": "[...] um efeito estético, portanto - de tal modo análogo ao produzido pelo original que o leitor da tradução possa afirmar, sem mentir, que leu o original" (BRITTO, 2012, p. 50).

O parâmetro tradutório estipulado - a produção de um efeito de literariedade análogo ao do texto original - pressupõe uma concepção de literatura e de linguagem estética. A proposta de Britto se fundamenta no conceito de "função poética", de R. Jakobson (2005), definida como aquela que se volta para a mensagem, para a própria linguagem; é a função poética que confere ao texto literário seu valor como objeto estético. Nesse ponto, a visão de literatura de Britto se aproxima da de Haroldo de Campos, na medida em que, para
Campos, a função poética jakobsoniana é o cerne do texto poético e deve ser o foco da recriação.

Ao discorrer sobre as diferenças entre original e tradução, Paulo Henriques Britto, em "Tradução e criação" (1999), oferece ao leitor suas reflexões sobre seus processos de escrita autoral e de tradução, a partir de rascunhos de seu trabalho. Com base na tradução de um poema de Wallace Stevens e no poema "Pessoana", de sua autoria, Britto revela com mais clareza sua posição em relação ao contraste que observa entre as duas práticas. Seus comentários sobre a tradução de "Sunday Morning", de Stevens, revelam a busca por soluções bem-sucedidas, tendo em vista a recriação de um poema em língua portuguesa que seja "correspondente" ao poema de Stevens. A criação de "Pessoana", por outro lado, não se origina de um texto "pronto", mas se inspira em outros textos poéticos.

Ao discorrer sobre a criação desse seu poema, Britto salienta seu empenho por encontrar uma voz própria: "Eu literalmente não sabia o que dizer; os versos iniciais me pareciam bons, mas não me ocorria nada que pudesse lhes dar prosseguimento que não tivesse sido dito antes por Fernando Pessoa" (BRITTO, 1999, p. 249). O poeta, então, afirma que conhece as fontes textuais de seu poema: "Autopsicografia", de Fernando Pessoa, e "Cantiga VII" de Sá de Miranda. Sobre a tradução do poema de Stevens, Britto observa que também se inspirou na poesia de Pessoa para construir sua versão em português.

Dessa experiência, o autor conclui que a diferença entre o modo como tradução e criação autoral se articulam com suas respectivas fontes diz respeito a dois movimentos, um de autonomização e outro de acercamento: "enquanto na tradução a estrutura é mais ou menos equilibrada, no caso da criação o movimento de autonomização é claramente predominante" (BRITTO, 1999, p. 250-1). Ou seja, tradução e criação ocorrem em sentidos opostos: a criação segue uma trajetória centrífuga, i.e., o autor conscientemente se afasta dos modelos literários que conhece, buscando sua própria voz. Já a tradução literária possui uma trajetória centrípeta, em que o tradutor evita afastar-se muito do texto original, para ecoar a voz do autor. 
Poeta e tradutor, Octavio Paz (2009), avalia de modo semelhante a distinção entre criar e recriar: "a atividade do tradutor é paralela à do poeta, com esta diferença marcante: ao escrever, o poeta não sabe como será seu poema; ao traduzir, o tradutor sabe que seu poema deverá reproduzir o poema que tem diante dos olhos" (PAZ, 2009, p. 27). Ele sustenta que a matéria prima do poeta é a linguagem em movimento; a do tradutor é a linguagem fixa do poema.

Esta questão é também alvo de interesse de Tânia Franco Carvalhal (1993, p. 47), para quem "a literatura e a tradução literária são práticas que podem esclarecer uma à outra". O escritor tem, assim como o tradutor, "uma série de referenciais (literários e não literários) que ele redimensiona de modo particular" (CARVALHAL, 1993, p. 47). Carvalhal apresenta uma breve análise da interação entre tradução e criação na obra do poeta-tradutor Theodomiro Tostes, sobre a qual afirma: "o ato de traduzir era para Tostes um estímulo à sua produtividade poética" (CARVALHAL, 1993, p. 48). Referindo-se à criação do poema "Canto a Leopardi”, a partir do poema "A si mesmo", de Giacomo Leopardi, traduzido por Theodomiro Tostes, Carvalhal (1993, p. 48) constata que o poeta-tradutor

não adotava 'a maneira' do poeta traduzido. [...] Mas elaborava seu poema como um diálogo intertextual no qual a intervenção do texto de outro se faz presente. [...] A experiência de transpor determinado autor o levava a entender melhor sua obra e a impregnar-se do universo poético do outro.

O fato de a escrita autoral e a tradução percorrerem caminhos distintos não anula a grande proximidade que existe entre os dois procedimentos. Ler, interpretar, narrar, traduzir, poetizar e recriar confundem-se no universo complexo das trocas entre formas e ideias, línguas e mídias. O mais recente livro de poesia de Paulo Henriques Britto, Nenhum mistério (2018), pode ser visto como um exemplo primo da mútua fecundação entre tradução e criação literária, como pretendemos mostrar. O título do livro provém da tradução realizada por Britto do poema “One art” (2001) de Elizabeth Bishop, em que se lê, no primeiro verso: "A arte de perder não é nenhum mistério" ("The art of losing isn't hard to master"). A tradução também se vincula a dois poemas do livro, de autoria de Britto:
"Nenhuma arte" e "Nenhum mistério". Além disso, seu poema "Ao sair da sala" parece dialogar com "As you leave the room" de Wallace Stevens (poema cujo trecho serve de epígrafe ao poema de Britto), poeta também traduzido por Britto.

\section{3. "ONE ART"}

Como mencionado, o título Nenhum mistério inspira-se na tradução de Britto do poema "One Art" (2001), da consagrada poeta estadunidense Elizabeth Bishop:

\begin{tabular}{|c|c|}
\hline $\begin{array}{l}\text { One Art (Elizabeth } \\
\text { Bishop) } \\
\text { The art of losing isn't hard } \\
\text { to master, } \\
\text { So many things seem filled } \\
\text { with the intent } \\
\text { To be lost that their loss is } \\
\text { no disaster. }\end{array}$ & $\begin{array}{l}\text { Uma Arte (trad: Paulo } \\
\text { Henriques Britto) } \\
\text { A arte de perder não é } \\
\text { nenhum mistério; } \\
\text { tantas coisas contêm em si } \\
\text { o acidente } \\
\text { de perdê-las, que perder } \\
\text { não é nada sério. }\end{array}$ \\
\hline $\begin{array}{l}\text { Lose something every day. } \\
\text { Accept the fluster } \\
\text { of lost door keys, the hour } \\
\text { badly spent, } \\
\text { The art of losing isn't hard } \\
\text { to master. }\end{array}$ & $\begin{array}{l}\text { Perca um pouquinho a } \\
\text { cada dia. Aceite, austero, } \\
\text { a chave perdida, a hora } \\
\text { gasta bestamente. } \\
\text { A arte de perder não é } \\
\text { nenhum mistério. }\end{array}$ \\
\hline $\begin{array}{l}\text { Then practice losing } \\
\text { farther, losing faster: } \\
\text { places, and names, and } \\
\text { where it was you meant } \\
\text { to travel. None of these will } \\
\text { bring disaster. }\end{array}$ & $\begin{array}{l}\text { Depois perca mais rápido, } \\
\text { com mais critério: } \\
\text { lugares, nomes, a escala } \\
\text { subsequente } \\
\text { de viagem não feita. Nada } \\
\text { disso é sério. }\end{array}$ \\
\hline $\begin{array}{l}\text { I lost my mother's watch. } \\
\text { And look! My last, or } \\
\text { next-to-last, of three loved } \\
\text { houses went. } \\
\text { The art of losing isn't hard } \\
\text { to master. }\end{array}$ & $\begin{array}{l}\text { Perdi o relógio de mamãe. } \\
\text { Ah! E nem quero } \\
\text { lembrar a perda de três } \\
\text { casas excelentes. } \\
\text { A arte de perder não é } \\
\text { nenhum mistério. }\end{array}$ \\
\hline $\begin{array}{l}\text { I lost two cities, lovely } \\
\text { ones. And, vaster, } \\
\text { some realms I owned, two } \\
\text { rivers, a continent. } \\
\text { I miss them, but it wasn't a } \\
\text { disaster. }\end{array}$ & $\begin{array}{l}\text { Perdi duas cidades lindas. } \\
\text { E um império } \\
\text { que era meu, dois rios, e } \\
\text { mais um continente. } \\
\text { Tenho saudade deles. Mas } \\
\text { não é nada sério. }\end{array}$ \\
\hline $\begin{array}{l}\text { - Even losing you (the } \\
\text { joking voice, a gesture } \\
\text { I love) I shan't have lied. It's } \\
\text { evident } \\
\text { the art of losing's not too } \\
\text { hard to master } \\
\text { though it may look like } \\
\text { (Write it!) like disaster. } \\
\text { (BISHOP, 2001, p. 308) }\end{array}$ & $\begin{array}{l}\text { - Mesmo perder você (a } \\
\text { voz, o ar etéreo } \\
\text { que eu amo) não muda } \\
\text { nada. Pois é evidente } \\
\text { que a arte de perder não } \\
\text { chega a ser mistério } \\
\text { por muito que pareça } \\
\text { (Escreve!) muito sério. } \\
\text { (BISHOP, 2001, p. 309) }\end{array}$ \\
\hline
\end{tabular}


"One Art" é uma vilanela composta por dezenove versos e seis estrofes, sendo as cinco primeiras, tercetos, e a última, um quarteto. Em sua forma clássica, a vilanela tem dois refrãos, a saber, o primeiro e o terceiro versos do primeiro tercerto. Cada um desses refrãos aparece de forma alternada ao longo do poema até a última estrofe - o quarteto -, onde ambos aparecem. Em "One Art", um dos refrãos obedece à forma clássica: é o verso de abertura "The art of losing isn't hard to master"; o segundo refrão, porém, é apenas a rima final do terceiro verso, "disaster", em lugar do verso inteiro. Há também duas rimas finais que se repetem: palavras terminadas com o som "aster" "master / disaster"e "ent" e "continent / evident") com o primeiro e o terceiro verso do primeiro terceto aparecendo de forma alternada até a última estrofe, que inclui ambos. Como podemos observar, a tradução de Britto conserva a estrutura de vilanela, transformando os refrãos, respectivamente, em "A arte de perder não é nenhum mistério" e "sério", e mantendo as rimas finais "mistério" / "sério" para "master"/ "disaster", além de "continente" / "evidente" para "continent" / "evident".

Como visto anteriormente, Britto defende que a tarefa do tradutor literário é identificar as características mais importantes do texto original e procurar recriá-las no idioma de chegada com o maior grau de correspondência possível. Procuraremos observar esses aspectos em sua tradução de "One Art".

A escolha de "continente" e "evidente", por exemplo, resgata uma correspondência sonora com o original: Bishop escreve "continent" e "evident". A palavra "mistério" também remete a "disaster": ambas contêm vogais abertas e as sílabas tônicas recaem na segunda sílaba. Para manter as rimas, porém, o tradutor vê-se obrigado, às vezes, a utilizar palavras que não remetem ao sentido "exato" do original: ao traduzir, no primeiro terceto, "so many things seem filled with the intent" como "tantas coisas contêm em si o acidente", Britto preserva a proximidade sonora entre "intent" e "acidente", mas expressa a "ideia" de forma diferente: enquanto 0 original indica uma intencionalidade, talvez até uma fatalidade - a finalidade de muitas coisas é que sejam perdidas - a tradução se refere a um acidente: a perda pode ser inesperada, repentina, aleatória. No entanto, a ênfase na sonoridade não interfere na ideia de "fatalidade", pois ao dizer que as coisas "contêm em si o acidente de perdê-las", não deixa de atribuir às coisas seu próprio destino. Caso semelhante é a tradução de "accept the fluster" por "aceite, austero". É possível traduzir "fluster" por "agitação" ou "confusão" - que remeteriam a uma experiência mais próxima do estado emocional do eu lírico. A palavra "austero", embora rime com "mistério", "critério", sério", alude a um ato estoico, que sugere desprendimento, aceitação das perdas inerentes à vida. Observa-se que, nesse caso, Britto prioriza a sonoridade em detrimento do sentido

O próprio refrão "The art of losing isn't hard to master", recriado como "A arte de perder não é nenhum mistério", revela decisões do tradutor: a forma do original é cuidadosamente reproduzida e o sentido é recriado de modo a aproximar-se o máximo possível do original. Ambos expressam sentidos similares, porém imprimem ângulos ligeiramente diversos: o original afirma que "a arte de perder não é difícil de aprender", portanto, pode ser dominada; já a tradução leva o leitor a pensar que não é preciso dominar tal arte, uma vez que "a arte de perder não é nenhum mistério".

A repetição dos refrãos e das rimas enfatiza a mensagem do eu lírico - que se torna cada vez mais forte ao longo do poema, acompanhando o aumento do ritmo das perdas. Pode-se afirmar que o poema de Bishop é uma lição sobre perda e aceitação: o eu lírico, ao recordar as muitas perdas que sofreu, desde as menores ("a chave perdida, a hora gasta bestamente") até as maiores (duas cidades, um império, um continente, o ser amado), procura mostrar que a perda é inevitável ("tantas coisas contêm em si o acidente de perdê-las"), portanto não há saída senão aceitá-la, o que é uma triste ironia. Com a prática e com o tempo, é possível "acostumar-se" à perda: perder não é nenhum mistério, mas é uma arte. A tradução de Britto procura recriar aquilo que ele prioriza no poema de Bishop, conforme sua concepção de literatura: a sonoridade, o ritmo, a estrutura formal. 


\section{NENH(UMA) ARTE}

A perda é um tema amplamente explorado em Nenhum mistério. O título da obra retoma a tradução de Britto do trecho do refrão de "One Art", de Elizabeth Bishop, a quem o poeta homenageia com o poema "Nenhuma arte", de sua autoria, que abre o livro. Se "Uma arte" é o ensinamento, "Nenhuma arte" é o aprendizado: o eu lírico do poema de Britto cumpre o papel do discípulo-questionador, que reflete sobre a lição de seu mestre e não aceita a indiferença diante da perda. Ao analisarmos "Nenhuma arte" (BRITTO, 2018, p. 9-15), observamos que o eu lírico desafia a suposta ordem estabelecida: ora, se o que se recebe é tirado, "não cabe se queixar agora"? E se pergunta: "Mas não ter tido nunca nada não / seria bem melhor - ou menos mau?" (BRITTO, 2018, I, p. 9).

Em contraste com o poema de Bishop, a dor da perda se faz presente de maneira incisiva em "Nenhuma arte" (que, por ser extenso, será aqui analisado em partes): "onde o que foi desejo / (tudo que fica dói) / até hoje lateja" (II, p. 10). A perda é retratada como um aprendizado doloroso, que possivelmente nunca se alcance. O poema de Britto responde com imagens inquietantes ao desapego que "Uma arte" insiste em recomendar - ainda que com certa ironia em seu refrão: "perder não é nada sério":

Uma vida inteira passada
dentro dos confins de um corpo
junto ao qual vem atrelada
a consciência, peso morto
que acusa o golpe sofrido
e cochicha ao pé do ouvido
depois que o fato se deu:
nada que te pertence é teu.
(BRITTO, 2018, IV, p. 12)

"Nada que te pertence é teu", repete o eu lírico, até "aprender enfim / a cruel lição: / a que só se aprende / por subtração" (VI, p. 15). Em “Nenhuma arte”, Britto questiona a possibilidade de aceitação da perda, que Bishop propõe em "Uma arte": "nem tampouco ciência: / pois não há teoria - / só práxis - da ausência" (VI, p. 15).

É surpreendente a força poética que Britto extrai de seu diálogo com o poema da poeta estadunidense, com o qual tem grande intimidade por tê-lo traduzido. A relação entre tradução e criação em Britto se assemelha à que Tânia Carvalhal (1993, p. 48) observa em Theodomiro Tostes: Britto tece um diálogo intertextual com a "fonte" que inspira seu poema autoral. Para Carvalhal (1993, p. 48), "Isso comprova como a experiência de transpor determinado autor 0 levava [Tostes] a entender melhor sua obra e a impregnar-se do universo poético do outro". É importante ressaltar, contudo, que, no caso de Paulo Henriques Britto, o que está em jogo é muito mais do que uma experiência de "transposição"; o poeta parece sentir-se provocado, instigado, desafiado pelo poema que traduz, o que o leva a responder com um poema seu.

\section{NENHUM MISTÉRIO}

Enquanto "Nenhuma arte" é uma indagação sobre o sentido da arte de perder, em "Nenhum mistério" (BRITTO, 2018, p. 20), o eu lírico se empenha na busca de alguma finalidade para a vida (escassez) e para a morte (a perda): "Pois dessa matéria escassa / há que se tirar sustância" (BRITTO, 2018, p. 20). Se a dor e o sofrimento pela perda são o tema de "Nenhuma arte", "Nenhum mistério" retrata a perda como algo banal, como o fim anunciado, que se espera sem qualquer emoção ou assombro. A vida é uma narrativa cujo final é tão previsível, tão clichê, que só é lida porque não há alternativa.

Não há nenhum mistério nesta história
em que o culpado se anuncia
ainda na primeira hora,
$[.$.
Mesmo assim, esta
é a história lida
até por quem detesta
toda a inútil narrativa,
até por não haver alternativa.
(BRITTO, 2018, II, p. 21)

$A$ seção $V$ do poema retrata a desolação e a agonia de se estar preso nesse ciclo sem nexo. Pensar é um fardo. Se penso, logo existo: pensar é existir nos limites dessa narrativa inútil. A sensação é de confinamento: "E no entanto este teto tão perto / da cabeça, este chão frio demais, / estas paredes pensas, esta porta / que fecha como quem não se abre mais" ( $V$, p. 24). O pensamento é clausura, a vida é pesadelo inescapável, um espaço apertado demais: estamos encurralados. 
Na seção VIII, o poeta contempla: "Pois é mister que se aproveite / o que se tem, por mais daninho, que da pedra que há no caminho se extraia o leite" (BRITTO, 2018, p. 27). Para sobreviver, explica o eu lírico, é preciso extrair a sustância da pedra que há no caminho, único objeto-oportunidade que se coloca à frente do ser vivo, objeto real, sólido e intertextual - a pedra-metáfora que Drummond de Andrade colocou no meio do caminho.

Por fim, apesar de tanto que se pode conjecturar sobre essa sina dolorida e sem esperança, o poeta conclui:

Dentro da noite por fim construída há tempo para tudo, e muito espaço.

$[\ldots]$

É uma espécie de véspera. Calados, os cômodos esperam o raiar de alguma coisa como um dia. Ou não. (BRITTO, 2018, X, p. 29)

A narrativa continua, para além do poema: no silêncio da noite, aguarda-se o início de um novo dia, talvez, ou o fim da história. Mas o que quer que aconteça, tudo continuará igual para quem permanecer nesse ciclo, como o personagem de um filme continuamente reprojetado, condenado à espera inútil. Pois tal se anuncia na seção III do poema: "tente o que se tente, / acaba-se chegando sempre ao ponto exato de onde se partiu (o nada)" (p. 22). Em "Nenhum mistério", o começo nos leva ao final - "e o final / - que, é claro, já se sabia / desde o início" (p. 21) - que nos devolve ao começo - "É uma espécie de véspera. Calados, / os cômodos esperam o raiar" (p. 29). Entre o nascimento e a morte, o labirinto se fecha, sem deixar saída.

Em "Uma arte", o tradutor Britto se esmera na reprodução do ritmo, da sonoridade, da cadência do poema. Em "Nenhuma arte", o poeta se deixa estimular pela poesia de Bishop e se dirige à perda como o vazio inexorável e doloroso daquilo que nunca se teve ou se terá. Se Bishop repete, em "Uma arte", que "perder não é nenhum mistério", Britto enfatizará, em "Nenhum mistério", a falta como atributo do mero estar vivo, sem

\footnotetext{
1 "Stevens affirmed his own $v$ itality through four poems he had written" (BLOOM, 1980, P.153)

${ }^{2}$ Como o livro utilizado para referência é um e-book enão possui paginação, utilizamos o formato Kindle de
}

esperança de que possa ser diferente, de que algo possa mudar, pois qualquer desvio aleatório é apenas mais uma miragem. Nas traduções, como em seus poemas, observa-se um grande cuidado e investimento na forma.

\section{WALLACE STEVENS: "AS YOU LEAVE}

\section{THE ROOM"}

A primeira observação que os críticos e estudiosos costumam fazer em relação a "As you leave the room", do poeta estadunidense Wallace Stevens, é que o poema incorpora à composição - com pequenas, mas significativas alterações - quatro dísticos de seu poema "First Warmth". Por esse motivo, procuram relacionar os dois poemas, salientando a mudança de estado de espírito do eu lírico, sinalizada pelas alusões às estações do ano: "First Warmth" aponta para os primeiros sinais de calor que chegam com a primavera, enquanto "As you leave the room" alude à neve e ao inverno. Neste estudo, não exploramos os elos entre as duas criações de Stevens; tratamos "As you leave the room" como poema independente, que será cotejado à tradução de Britto e relacionado ao poema deste, "Ao sair da sala".

Em "As you leave the room", um dos últimos poemas escritos por Wallace Stevens, este "afirma sua própria vitalidade por meio de quatro dos muitos poemas que havia escrito", como declara o crítico literário Harold Bloom em Wallace Stevens: The Poems of Our Climate (1980, p. 158, nossa tradução ${ }^{1}$ ). Similarmente, Paulo Henriques Britto sustenta, na Apresentação de O imperador do sorvete (2017), onde se encontra sua tradução para o poema em pauta, que este trata de um "artista obcecado pela ideia de perfeição [que] contempla a própria obra com distanciamento crítico" (Posição 283²). "As you leave the room", porém, é mais do que uma reflexão de Stevens acerca de sua própria obra: é uma reflexão do poeta sobre sua vida, fortemente interligada com os poemas que escreveu.

localização ("Posição X”) para identificar os trechos citados. 
O eu lírico inicia o poema respondendo a um "você" descrito por Lensing como um "aliado ou segundo 'eu' que duas vezes refuta a vida esqueletal de Stevens, apontando para os poemas em si como evidência" (LENSING, 2001, p. 173, nossa tradução³). O poeta não é um esqueleto, pois seus poemas não são pensamentos de esqueleto. Ainda assim, o eu lírico indaga se viveu uma vida de esqueleto, através dos poemas, distante da realidade como ela de fato é: um "descrente da realidade". Há uma ruptura entre o mundo interior e o mundo exterior do poeta.

$\mathrm{Na}$ quinta estrofe, porém, ao lembrar-se da "neve que esquecera", algo que pode ser associado tanto aos sentidos físicos quanto à dimensão emocional, torna-se possível "emendar" tal ruptura: a lembrança da neve permite o acesso a uma realidade maior, a uma apreciação da realidade. Assim, há "uma elevação", como se o eu lírico estivesse próximo de alcançar uma "correspondência" completa entre o real e o irreal (exterior e interior), a "perfeição" à qual Britto se refere na Apresentação de O imperador do sorvete (2017). No entanto, Stevens conclui que nada mudou, apenas 0 irreal, como se nada tivesse mudado. A dúvida permanece: a mudança ocorre apenas no âmbito irreal - mas, poderia tal mudança permitir uma maior apreciação do real?

A conclusão de "As you leave the room" é ambígua: conectar-se à realidade através da poesia significa, simultaneamente, uma apreciação única de uma realidade e um distanciamento das "coisas comuns" da realidade.

\section{7. "AO SAIR DA SALA" - A TRADUÇÃO DE}

\section{BRITTO}

Traduzido para o português por Britto, "Ao sair da sala" integra O imperador do sorvete e outros poemas (2017), ao lado de outros poemas de Stevens.

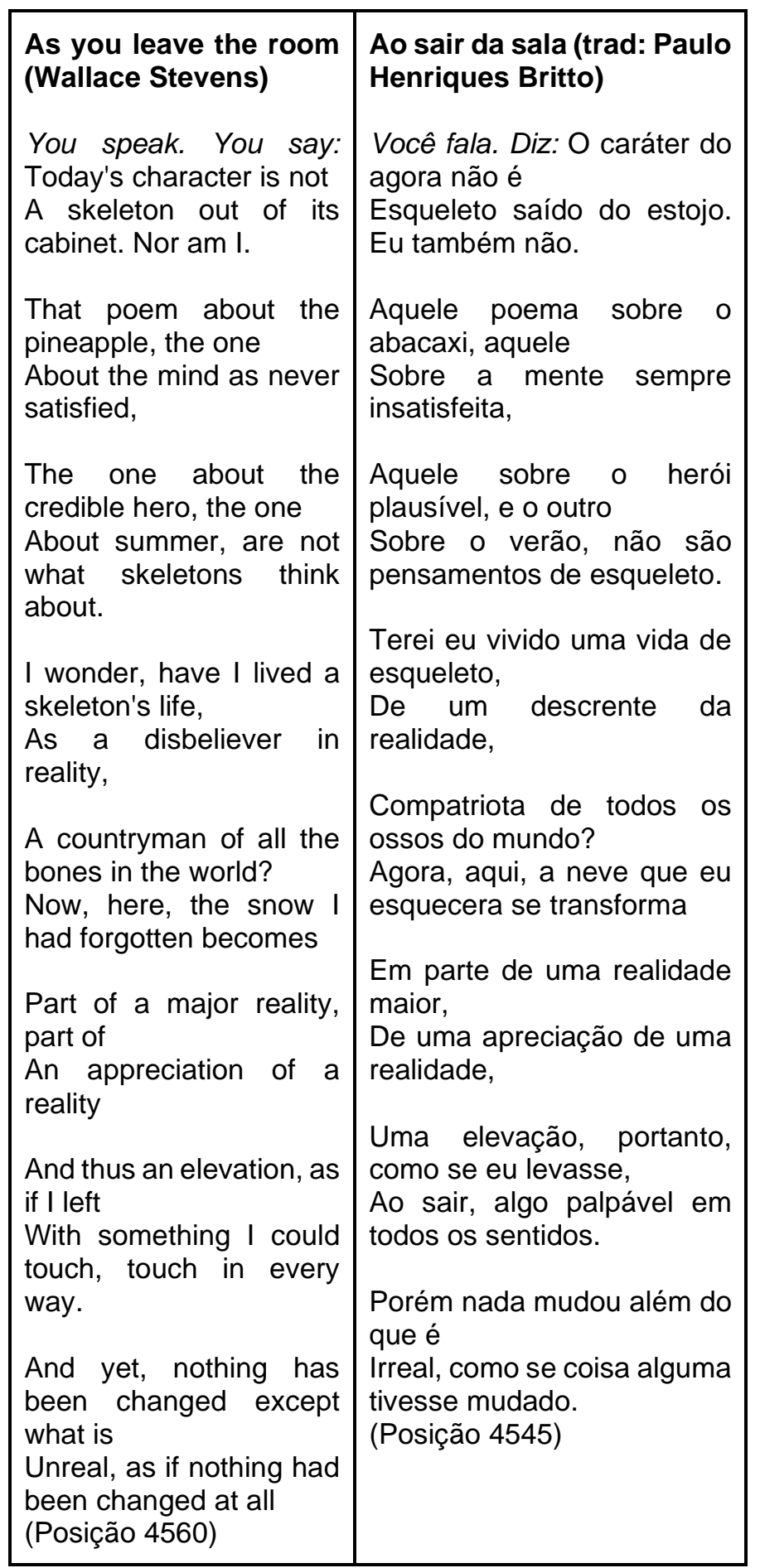

A tradução segue uma estrutura semelhante à do poema de Wallace Stevens: oito dísticos sem esquema fixo de rimas. Para seguir o padrão de versos curtos do inglês, Britto recorre à concisão poética. Assim, no segundo dístico, em vez de traduzir o verso "About the mind as never satisfied" por "Sobre a mente 'como' nunca satisfeita", o poeta escolhe "Sobre a

\footnotetext{
3 "That 'you' is an ally or other self who twice denies Stevens' skeletal life and does so by pointing to the poems themselves" (LENSING, 2001, p. 173).
} 
mente sempre insatisfeita". Outra possível opção, "Sobre a mente nunca satisfeita", possibilitaria maior proximidade com o poema em inglês, mas a tradução de Britto, "Sobre a mente sempre insatisfeita", valoriza os aspectos sonoros do original, resgatando a rima interna mind/satisfied que se transforma em mente/sempre. Do ponto de vista da forma, portanto, Britto parece ter optado, como vimos em suas outras traduções, por seguir de perto o texto de origem (tendência centrípeta), recriando diversos recursos literários, como se observa, por exemplo, na sonoridade do título "Ao sair da sala", que capta o ritmo e a cadência de "As you leave the room".

Ainda sobre o título do poema, observa-se que "As you leave the room", que poderia ser traduzido por "Quando você sai da sala", ou "Quando você sair da sala", torna-se "Ao sair da sala". O verbo "leave" poderia ter sido traduzido como "partir", mas a escolha por "sair", além de realçar a aliteração com "sala", preserva a conotação do original, que não evoca a ideia de "morte" de forma tão explícita quanto o verbo "partir". O "you" do título denota um ser hipotético, que simultaneamente é e não é o eu lírico. Esse segundo ser reaparece na primeira estrofe do poema em inglês: "You speak. You say". Na tradução, o pronome aparece pela primeira vez no verso que inicia o poema: "Você fala. Diz: O caráter do agora não é / Esqueleto saído do estojo. Eu também não". O eu lírico responde a essa voz, afirmando que também não é um esqueleto saído do estojo. Embora não se refira explicitamente a um "você" no título, "Ao sair da sala" mantém o sentido aberto de "As you leave the room", visto que o pronome em inglês não sinaliza um interlocutor específico.

Na penúltima estrofe, a tradução de "as if I left / With something I could touch, touch in every way" por "como se eu levasse, / Ao sair, algo palpável, em todos os sentidos" é interessante porque recupera e enfatiza nuanças do poema de Stevens. A sensibilidade poética de Britto se revela na tradução: "como se eu levasse, ao sair" retoma de forma mais clara o título dado ao poema, do que a tradução palavra por palavra: "como se eu saísse / Com algo que pudesse tocar". Também a tradução de "something I could touch, touch in every way" por "algo palpável, em todos os sentidos", realça, pela ambiguidade da palavra "sentido", em português, aquilo que Stevens descreve como uma apreciação da realidade, isto é, a realidade apreciada por meio dos sentidos físicos, pela união dos mundos exterior e interior do poeta.

Após essa breve reflexão sobre a tradução, passamos à análise do poema "Ao sair da sala", de autoria de Britto (Nenhum mistério, 2018), visando encontrar evidências da relação entre tradução e criação literária na obra do poeta-tradutor.

\section{8. "AO SAIR DA SALA": COMO SE ALGUMA}

\section{COISA TIVESSE MUDADO}

Ao sair da sala

And yet, nothing has been changed except what is

Unreal, as if nothing had been changed at all. (Wallace Stevens)

\section{Você ao sair da sala escuta um murmúrio discreto. Pensa: é alguém que me fala em pleno discurso direto.}

Porém não é nada disso. É o murmúrio impessoal do silêncio quebradiço que se ouve mal e mal

onde não há o que se ouça.

Se ao seu ouvido ele soa como algo que talvez possa emanar de alguma pessoa,

é pra desdizer a certeza de que, atrás da porta fechada, na sala ainda há pouco acesa agora não há nada. (BRITTO, 2018, p. 68)

Tanto o título quanto a epígrafe do poema "Ao sair da sala", de Britto, aludem claramente ao poema "As you leave the room" de Wallace Stevens, e configuram um convite para que o leitor (re)leia o poema de Stevens. O trecho citado por Britto é a última estrofe do poema de Stevens, traduzido por Britto como: "Porém nada mudou além do que é / Irreal, como se coisa alguma tivesse mudado" (STEVENS, 2017, posição 4545). Observa-se a clara afinidade temática entre os poetas.

A epígrafe introduz a ideia da enigmática relação entre o real e o imaginado, tema frequente na 
obra de Stevens, como nota Paulo $H$. Britto na Apresentação de O imperador do sorvete: "a relação entre imaginação e realidade, poesia e verdade" (BRITTO, 2017, Posição 208) é um dos temas essenciais do poeta estadunidense.

Em "Ao sair da sala", Britto apresenta uma conjunção entre "as coisas tais como são e as coisas imaginadas"; o eu lírico encontra-se em uma situação na qual o véu entre o real/empírico e o imaginado/imaterial parece dissolver-se: ao sair da sala vazia, pensa escutar uma voz que se dirige a ele - mas é apenas o ruído impessoal do silêncio. A dúvida, no entanto, perdura: "é pra desdizer a certeza / de que, atrás da porta fechada, / na sala ainda há pouco acesa / agora não há nada" (BRITTO, 2018, p. 68). Seria a imaginação preenchendo o vazio? Ou há uma presença real do outro lado da porta?

Ainda na introdução de $\mathrm{O}$ imperador do sorvete, Britto destaca a importância da interação entre imaginação e realidade na obra de Stevens, para quem

a imaginação é a função básica da consciência, e a realidade é, ao menos em grande parte, um produto desta. Não há motivo, portanto, para valorizar o mundo das "coisas como são" em detrimento de outros produtos da imaginação [...] (BRITTO, 2017, Posição 221)

Se a citação de Stevens pode nos revelar algo sobre o poema de Paulo Henriques Britto, é que a voz imaginada pelo "você" - desdobramento ou duplo do eu lírico - é tão real quanto a percepção da realidade, uma vez que a própria imaginação é real, ainda que imaterial. Respondendo ao "você" do poema, o eu lírico declara que não se trata da voz de alguém, mas do "murmúrio impessoal do silêncio", constatação que se revela paradoxal, ao vincular e associar murmúrio e silêncio. O primeiro verso da terceira estrofe busca ser inequívoco e taxativo: "não há o que se ouça"; porém, em seguida, o eu lírico adverte que, se o silêncio the parece emanar de alguém é justamente para dissipar a certeza de que nada há na sala há pouco acesa: "Se ao seu ouvido ele soa / como algo que possa / emanar de alguma pessoa, / é pra desdizer a certeza / de que, atrás da porta fechada, / na sala ainda há pouco acesa / agora não há nada".
O poema apresenta um desfecho que não dissolve a indecisão entre fantasia e realidade, mas, ao contrário, a legitima. Ao oscilar entre presença e ausência, voz e silêncio, percepção pessoal e certeza, mantém-se uma indeterminação perturbadora.

O poema de Stevens, escrito pouco antes de sua morte, promove uma reflexão sobre sua obra e sua vida, quando o poeta sente que está prestes a "sair da sala": morrer. Britto escolhe terminar seu livro Nenhum mistério tecendo um diálogo com Stevens: "Ao sair da sala", no caso de Britto, aponta para o fim do livro, o término da obra, também uma espécie de morte - fim já previsto desde o início, visto que a morte é um vilão que se anuncia logo na primeira hora.

Em A tradução literária (2012), Paulo Henriques Britto afirma que o processo de criação poética segue uma trajetória centrífuga, em que o autor conscientemente se afasta dos modelos literários que conhece, buscando sua própria voz. De fato, notamos que a voz que se ouve em "Ao sair da sala" é a de Britto, não a de Stevens. Ainda assim, o poema estabelece um diálogo estreito com a temática apresentada por Stevens: o poeta brasileiro reconhece a dimensão do "não real" proposta pelo poeta estadunidense, e responde com uma interpretação própria acerca da questão poetizada por ele. Assim, há uma relação visível entre as obras, pois ambos os poetas chegam à percepção de que a tensão entre realidade e imaginação, exterior e interior, material e imaterial continua, apesar dos esforços para desfazê-la.

Quanto à forma, diferentemente dos versos livres de Stevens, Britto opta por construir seu próprio poema com rimas alternadas em estrofes, versificação, cadência e aliterações, como o som sibilante que se faz ouvir em: "É o murmúrio impessoal / do silêncio quebradiço / que se ouve mal".

\section{CONSIDERAÇÕES FINAIS}

O trabalho estético de Paulo Henriques Britto com a linguagem corrobora a asserção de Octavio Paz sobre a relação de uma "mútua fecundação" entre escrever e reescrever (PAZ, 2009, p. 27). Britto se inspira na poeticidade do texto original para recriar 0 
que pode ser recriado, e reproduzir, na tradução, um efeito de literariedade (BRITTO, 2012, p. 50) semelhante ao que depreende do original, realçando que essa etapa deve ser feita com cuidado: "a tradução é, por definição, a operação de leitura mais cuidadosa que se pode imaginar" (BRITTO, 2012, p. 51).

O produtivo processo de intercâmbio entre as duas atividades evidencia-se, também, quando observamos que os textos traduzidos por Britto influenciaram sua prática de criação poética: como exposto, os poemas de E. Bishop e W. Stevens agem como estímulos que o instigam a criar novos poemas, a partir de um diálogo profundo que dá vazão a uma obra singular e pessoal, que, ainda assim, não deixa de homenagear seus antecessores.

A reflexão de Paz (2009, p. 15), "cada texto é único e, simultaneamente, é a tradução de outro texto", transparece na intertextualidade que caracteriza a (re)escrita de Paulo H. Britto: além de remeter a obras que traduziu, são feitas referências a outros textos, como à pedra "no meio do caminho", de Drummond de Andrade, em "Nenhum mistério". Ademais, como pontuamos, Britto revela, no ensaio "Tradução e criação" (1999), algumas das fontes que influenciaram tanto sua tradução de "Sunday Morning" de Stevens, quanto a criação de seu poema "Pessoana". O poeta reflete sobre o forte apelo que os versos de Pessoa têm sobre suas escolhas tradutórias: "Seja como for, o fato é que o texto de Pessoa se intrometeu de tal modo em minha tradução que podemos, dentro da nossa hipótese de trabalho, tomá-lo aqui como segundo textofonte" (BRITTO, 1999, p. 246-7).

As palavras de Britto dão testemunho do imenso valor que representa o repertório literário para escritores criativos. A escrita literária leva aquele que é poeta e tradutor a "entender melhor sua obra e impregnar-se do universo poético do outro", como pontua Carvalhal (1993, p. 50) a respeito da relação entre tradução e criação na obra de Theodomiro Tostes.

Como observa Autor 2 em seu estudo sobre tradução e criação em Britto (2020, p. 36): "Ao traduzir Bishop e Stevens, Paulo Henriques Britto interage com os textos, desfazendo e refazendo seus tecidos poéticos". E assim procede, graças à experiência íntima que tem com os recursos e procedimentos literários -experiência que Haroldo de Campos define como "vivência interior do mundo e da técnica do traduzido" (CAMPOS, 2013, p.14). Igual percepção é expressa por Britto, quando pondera sobre seu labor:

Não há melhor laboratório para a criação poética do que a tradução de poesia. O trabalho de recriar no seu próprio idioma a experiência poética vivida numa língua alheia apresenta ao poeta-tradutor todos os problemas formais da criação poética, fornecendo-Ihe apenas um ponto de partida de natureza já textual, o que nem sempre é o caso quando se trata de compor um poema novo (BRITTO apud ASEFF, 2020, p. 98)

Traduzir e criar são práticas comunicantes, complementares que, para Britto, têm processos próprios e ocorrem em sentidos opostos. Segundo o que pudemos observar no presente estudo, Britto é coerente com tal visão: suas traduções procuram aproximar-se do texto de origem e seus poemas, embora dialoguem diretamente com os de Bishop e de Stevens, são poemas autônomos, que retratam as concepções e os sentimentos do poeta.

Nas duas traduções aqui analisadas, Britto privilegia os aspectos formais dos poemas, buscando preservar também os aspectos semânticos e conotativos. Coerente com sua teorização, preserva aquilo que considera importante, com base em critérios pessoais que estão ligados aos valores da comunidade interpretativa literária de seu tempo: as rimas, a métrica, o tom e o teor dos poemas.

Por sua qualidade, o trabalho tradutório de Paulo Henriques Britto enriquece a literatura nacional e reforça o lugar de Bishop e Stevens no cânone transnacional. Contribui para isso o fato de que Britto figura no cânone nacional de poetas contemporâneos, além de seu nome como tradutor literário ser uma referência para leitores no Brasil e fora dele. Por meio de suas traduções, temos acesso a uma nova dimensão da obra de poetas como Bishop e Stevens, pois estamos diante da visão de um poeta sobre as obras de seus pares. Britto confirma a forte afinidade entre criar e traduzir: a poesia de Nenhum mistério (2018) é uma bela prova disso. 


\section{REFERÊNCIAS}

ARROJO, Rosemary. A que são fiéis tradutores e críticos de tradução? Paulo Vizioli e Nelson Ascher discutem John Donne. In: Tradução, desconstrução e psicanálise. Rio de Janeiro: Imago, 1993, p. 15-26.

ARROJO, Rosemary. Oficina de tradução: a teoria na prática. 5. ed. São Paulo: Ática, 2007, p. 11-57.

ASEFF, Marlova Gonsales. Poetas-tradutores: quando a tradução encontra a criação. Cadernos de Tradução. Florianópolis, v. 40, no 3, p. 92-108, set-dez, 2020.

\section{AUTOR 2}

BISHOP, Elizabeth. O iceberg imaginário e outros poemas. Trad. Paulo Henriques Britto. Edição bilíngue. São Paulo: Companhia das Letras, 2001, 370 p.

BLOOM, Harold. Wallace Stevens: The Poems of Our Climate. Ithaca: Cornell University Press, 1980, 416 p.

BORGES, Jorge Luis. As versões homéricas. In: Discussão. Trad. Cláudio Fonari. São Paulo: DIFEL, 1986, p. 71-78.

BRITTO, Paulo Henriques. A tradução literária. Rio de Janeiro: Civilização Brasileira, 2012, 157 p.

BRITTO, Paulo Henriques. Nenhum mistério. São Paulo: Companhia das Letras, 2018, 72 p.

BRITTO, Paulo Henriques. Tradução e criação. Cadernos de Tradução (UFSC), n. IV, 1999, p. 239-262.

CAMPOS, Haroldo de. Da tradução como criação e como crítica. In: TÁPIA, Marcelo; NÓBREGA, Thelma Médici (Org.). Haroldo de Campos: Transcriação. São Paulo: Perspectiva, 2013, p. 1-18.

CAMPOS, Haroldo de. Transluciferação mefistofáustica. In: Deus e o Diabo no Fausto de Goethe. São Paulo: Perspectiva, 1981, p. 179-209.

CARVALHAL, Tânia Franco. A tradução literária. Organon. Porto Alegre: Instituto de Letras, v. 7, n. 20, 1993, p. 47-52. Disponível em: http://www.seer.ufrgs.br/ organon/article/viewFile/39381/25174. Acesso em: 10 jan. 2020 .

JAKOBSON, Roman. Linguística e poética. In: Linguística e comunicação. Trad. Izidoro Blikstein; José Paulo Paes. São Paulo: Cultrix, 2005, p. 118-162.

LENSING, George. Wallace Stevens and the Seasons. USA: Louisiana State University Press, 2001, 392 p.

PAZ, Octavio. Tradução: literatura e literalidade. Trad. Doralice Alves Queiroz. Belo Horizonte: FALE/UFMG, 2009, p. 9-33. Disponível em:

http://www.letras.ufmg.br/padrao_cms/documentos/event os/vivavoz/traducao2ed-site.pdf. Acesso em: 21 out. 2019 .
STEVENS, Wallace. O imperador do sorvete e outros poemas. Trad. Paulo Henriques Britto. São Paulo: Companhia das Letras, 2017, 336 p. E-book.

\section{COMO CITAR ESSE ARTIGO}

DARIN, Leila Cristina de Melo; BARTOLOMEU, Vivian Chazan. Criação e recriação: um olhar para a obra do poeta e tradutor Paulo Henriques Britto. Signo, Santa Cruz do Sul, v. 46, n. 87, sep. 2021. ISSN 1982-2014. Disponível em: $<$ https://online.unisc.br/seer/index.php/signo/article/view/16 258>. doi:https://doi.org/10.17058/signo.v46i87.16258. 